\title{
EXTRACTING VEGETATION INFORMATION FROM SATELLITE DATA FOR THE NILWALA CATCHMENT AREA, SOURTHERN SRI LANKA
}

\author{
S. Pathirana \\ School of Enviornmental Science \& Management, \\ Southern Cross University, Lismore NSW 2480 - Australia
}

It is evident that increasing human activitics on forest resources can lead to floods, soil crision, loss of bio diversity, and incrcasc in atmospleric gases causing global warming. Sustainable management of forcst resources requires accuratc data on the current status of the cnvironment as well as tools to support the decision making process. Remote Scnsing and Gcographical Information Systems have increasingly becn used as decision support tools. Particulaly, recent advancements in satclite remote scnsing have facilitatcd acquiring valuable data and information in assessing the current status of the environment at varying levels of detail. The purpose of this study is to assess the potential of satclite remote scnsing in vegetation mapping of the Nilwala catchment arca of Southernn Sri Lanka. The paper prescnts the preliminary work amid at extracting vegctation information from Landsat TM and ETM data. The maps produced applying image processing techniques such as image differencing, Normalised Difference Vegetation Index (NDVI), ISOCLUSS unsupervised classification and Tasseled Cap Transformation show the extcnt, quality and change of vegetation in the catchment arca. Information derived from satcllite data can further be uscd in modeling crosion potcntial in agricultural arcas, mapping the flood risk, and land cover and land use change analysis when combine with geographical information. 